\title{
KUALITAS INFORMASI SISTEM KEUANGAN DESA PASCA PENGEMBANGAN APLIKASI
}

\author{
Intan Rakhmawati \\ Fakultas Ekonomi dan Bisnis Universitas Mataram \\ intanrakhmawati@unram.ac.id \\ Siti Atikah \\ Fakultas Ekonomi dan Bisnis Universitas Mataram \\ siti.atikah@unram.ac.id
}

\begin{abstract}
The village government in the West Nusa Tenggara region has implemented village financial management through application of Village Financial System - Sistem Keuangan Desa (Siskeudes). The application has been repaired and updated several times. This study aims to determine the comparison of information quality of village financial system, when operated with Siskeudes V1.0.R1.06 with Siskuedes V2.0. R.0.1, based on Permendagri Number 20 Year 2018. The researcher conducted a content analysis by comparing the outputs of the two Siskeudes versions. Assessment of the quality of the process and information 2 Siskeudes version were analyzed by interpretive methods.

The results showed that information quality from Siskeudes Version 2.0 R.0.1. better and integrated with documents at the planning and budgeting stages, compared with previous version Siskeudes. It caused of Siskeudes version 2 already have using activity package in the expenditure, so the village must be able to estimate the expenditure that will be absorbed by each activity. In Siskeudes version 2, in the reporting stage, there have also been additional reports at tax report, because it also adjusts with Minister of Finance Regulation (PMK) Number 193/PMK.07/ 2018.

On Siskeudes Version 2.0 R.0.1., have also used OM-SPAN for reporting to the ministry. The results of this study are expected to be useful for the Community and Village Empowerment Agency (DPMD) to train verifiers at the sub-district level.
\end{abstract}

Keywords: Quality of information, Village Financial System 


\begin{abstract}
Abstrak
Pemerintah desa di wilayah Nusa Tenggara Barat telah melaksanakan pengelolaan keuangan desa melalui aplikasi Sistem Keuangan Desa (Siskeudes). Aplikasi tersebut telah beberapa kali diperbaiki dan diperbaharui. Penelitian ini bertujuan untuk membandingkan kualitas informasi laporan keuangan desa saat dioperasikan dengan Siskeudes V1.0.R1.06 dengan Siskuedes V2.0. R.0.1., berdasarkan Permendagri Nomor 20 Tahun 2018. Peneliti melakukan analisis isi dengan membandingkan output kedua vers i Siskeudes. Penilaian atas kualitas proses dan informasi 2 versi Siskeudes dianalisis dengan metode interpretif.

Hasil penelitian menunjukkan bahwa kualitas proses dan informasi Siskeudes Versi 2.0 R.0.1. lebih baik dan terintegrasi dengan dokumen pada tahap perencanaan dan penganggaran, dibanding dengan Siskeudes Versi 1.0.R1.06. Hal ini dikarenakan Siskeudes versi 2 sudah menggunakan Paket Kegiatan dalam pos Belanja, sehingga desa harus mampu memperkirakan belanja yang akan diserap oleh setiap kegiatan. Dalam Siskeudes versi 2, pada tahap berkas laporan (output), sudah terdapat pula penambahan laporan pada semua tahapan hingga laporan pajaknya, sesuai dengan arahan PMK 193/PMK.07/2018. Siskeudes Versi 2.0 R.0.1. juga sudah menggunakan OMSPAN untuk pelaporan ke kementerian. Hasil penelitian ini diharapkan bermanfaat bagi Dinas Pemberdayaan Masyarakat dan Desa (DPMD) untuk melatih calon verifikator di tingkat kecamatan.
\end{abstract}

Kata kunci: Kualitas informasi, Sistem Keuangan Desa

\title{
PENDAHULUAN
}

Pemerintah desa telah diberikan kewenangan oleh Kementerian Desa, Transmigrasi, dan Pembangunan Daerah Tertinggal (PDT) dalam pengelolaan pemerintahan, sumber daya alam, serta kekayaan desa. Tidak hanya oleh 1 kementerian, pemerintah desa juga diberikan kewenangan oleh Kementerian Dalam Negeri (Kemendagri) dan Kementerian Keuangan untuk pengelolaan keuangan melalui angggarannya secara mandiri, baik melalui Dana Desa maupun Alokasi Dana Desa. Kewenangan ini harus dilaksanakan oleh pemerintah desa berdasarkan asas pelaporan dan pertanggungjawaban yang dilaksanakan melalu Sistem Keuangan Desa (selanjutnya disingkat Siskeudes). Lebih jauh lagi, pertanggungjawaban harus dilaksanakan dengan prinsip transparansi, dan hal ini juga dikontrol oleh Kementerian Informasi dan Komunikasi (Kominfo). 
Sistem informasi keuangan disediakan untuk mempermudah pemerintah desa dalam melaporkan dan mempertanggungjawabkan keuangan desa. Namun, pemerintah desa mengakui masih mengalami kesulitan dalam mengaplikasikan Siskeudes. Kesulitan ini, diakui oleh salah satu pemerintah desa, disebabkan kurang memahami proses pembukuan, harga pasar yang melebihi pagu dan kurang intensifnya pelaksanaan administrasi (Atikah, Hendri, \& Rakhmawati, 2019). Menurut Malahika, et al (2018) kelemahan dari Siskeudes versi lama sering mengalami gangguan sistem (error) pada saat proses penginputan, data tidak terinput dengan baik ataupun halaman entri tidak muncul.

Kemampuan sumber daya manusia dalam mewujudkan pemerintah desa yang bertanggungjawab dan transparan sangat penting. Hal ini diakui oleh Muhsyaf, dkk (2016), Husna \& Syukri (2016), Munti \& Fahlevi (2017), Sulina, dkk (2017), Malahika, dkk (2018), Juardi, dkk, (2018) dan Atikah, dkk (2019). Kekeliruan dalam pelaksanaan sistem keuangan muncul karena adanya perbedaan interpretasi atas suatu aturan dan memaknai suatu nama akun dalam laporan pertanggungjawaban. Kekeliruan yang terjadi dalam penerapan siskeudes antara lain pemilihan kode akun mata anggaran yang kurang tepat, dokumen pendukung yang kurang, atau perhitungan pengenaan pajak yang kurang tepat.

Suatu sistem informasi tidak pernah lalai dari pengembangan atau perbaikan sistem. Hal ini juga terjadi pada SISKEUDES. Terlebih pada bulan April 2018, Kementerian Dalam Negeri telah menerbitkan Permendagri Nomor 20 Tahun 2018 tentang Pengelolaan Keuangan Desa, untuk merevisi Permendagri Nomor 113 Tahun 2014 dan Permendagri Nomor 114 Tahun 2014. SISKEUDES turut mengalami revisi, dengan digunakannya aplikasi Siskeudes versi 2.0. Penelitian ini bertujuan mengetahui kualitas informasi yang dihasilkan oleh Siskuedes V2.0. dibandingkan dengan Siskeudes versi sebelumnya. Hasil penelitian ini diharapkan bermanfaat bagi peneliti lain atau bagi pendamping desa dalam proses pembinaan atau pendampingan di desa.

\section{TELAAH LITERATUR DAN PENGEMBANGAN HIPOTESIS}

Model yang digunakan untuk mengevaluasi Siskeudes pada penelitian ini yaitu DeLone and McLean Information System Success Model. Model kesuksesan Siskuedes V2.0. R.0.1. ditinjau dari kualitas informasi. Kualitas suatu informasi yang dihasilkan dipengaruhi oleh proses yang terjadi.

Kualitas proses didefinisikan sebagai akurasi, kehandalan, dan efisiensi dalam proses input data hingga menjadi output, yakni laporan. Kualitas proses dilihat dari akurasi akun dan jenis pajak, automatically error recovery, serta 
kemudahan dan ketertelusuran sistem untuk menginisiasi kebutuhan tiap desa yang berbeda, serta pencocokan antar fase pengelolaan keuangan desa (perencanaan, pengganggaran, penatausahaan, pelaporan, dan pertanggungjawaban), berdasarkan semua regulasi yang terkait. Ketertelusuran dan pencocokan ini juga untuk mengukur kualitas informasi (kualitas keluaran berupa laporan) dari Siskeudes.

Aplikasi Siskeudes telah mengalami beberapa penyesuaian dari versi sebelumya. Penyesuaian terakhir terkait dengan dirilisnya peraturan terbaru Permendagri 20 Tahun 2018 yang bertujuan untuk memenuhi kebutuhan desa. Penyesuaian tersebut berupa penambahan 1 parameter, yaitu Parameter Output Kegiatan Dana Desa sehingga pada versi terbaru ini terdapat 10 (sepuluh) parameter. Selain itu, dalam Siskeudes V2.0 R.0.1. ini juga terdapat peningkatan security Database Access (pada password) dan Security SQLServer, penyempurnaan perhitungan sisa anggaran atas pengembalian sisa belanja, dan Upgrade SML sehingga bisa menarik database desa otomatis dari katalog.

\section{METODE PENELITIAN}

Penelitian ini merupakan penelitian content analysis untuk menganalisis kualitas informasi. Peneliti menggunakan data latihan yang diolah dengan Siskeudes V1.0.R1.06, kemudian dibandingkan Siskeudes V2.0 R.0.1. Data diolah dengan membandingkan proses dan keluaran dari Siskeudes V1.0.R1.06 dan Siskeudes V2.0 R.0.1, dan metode yang digunakan adalah metode interpretif.

Kualitas informasi digunakan untuk mengukur kualitas keluaran dari sistem informasi, baik kelengkapan, ketepatan, maupun keandalan data input hingga menjadi laporan. Termasuk dalam pengukuran ini adalah akurasi, kehandalan, dan efisiensi dalam seluruh proses.

\section{HASIL PENELITIAN DAN PEMBAHASAN}

SISKEUDES sudah mulai digunakan oleh pemerintah desa tahun 2016. Badan Pengawasan Keuangan dan Pembangunan secara berkesinambungan telah memberikan pelatihan menggunakan aplikasi ini. Bulan Agustus 2019, pemerintah desa sudah mulai mengoperasionalkan aplikasi Versi 2.0 R.2.0.2, atau versinya yang terbaru. Siskeudes versi baru, masih menggunakan koneksi data melalui ODBC Access. Hal ini berarti bahwa pengguna dapat mengakses aplikasi tanpa harus memasang database aplikasi, karena dalam ODBC, terdapat banyak API (Application Programming Interface), yang memungkinkan koneksi aplikasi melalui sistem manajemen database. Driver 
ODBC Siskeudes juga terhubung dengan Ms. SML Server (untuk Pemerintah Kabupaten), ataupun dengan Ms. SQL Server (untuk Pemerintah Kota), dan Ms. Access.

Dalam Siskeudes V2.0 R.0.1. ini juga seperti versi sebelumnya, terdapat security Database Access (pada password) dan Security SQLServer, penyempurnaan perhitungan sisa anggaran atas pengembalian sisa belanja, dan Upgrade SML sehingga bisa menarik database desa.

Pada menu File yang tersambung dengan menu Tools, juga tetap ada update SML Pemda. Penggantian nama pemerintah kabupaten pada file Simulasi dilakukan dengan mekanisme SML Pemda, sedangkan untuk pemerintah kota, dengan mekanisme SQL Pemda. Baik user SML maupun SQL diberikan dari Ditjen Bina Pemdes. Sementara untuk pemerintah kabupaten, untuk memasukkan SML Desa, dapat dilakukan melalui menu Impor Kodefikasi Desa. Sementara untuk update user desa/kecamatan, hal ini merupakan kewenangan pemerintah kabupaten/kota.

Selanjutnya, pada menu Parameter, pengisian Siskeudes adalah kewenangan Pemda, karena tersambung dengan SML Pemda, kecuali pada sub menu Referensi Peraturan, karena mengacu dari Perdes, dan menu Rekening Bank Desa.

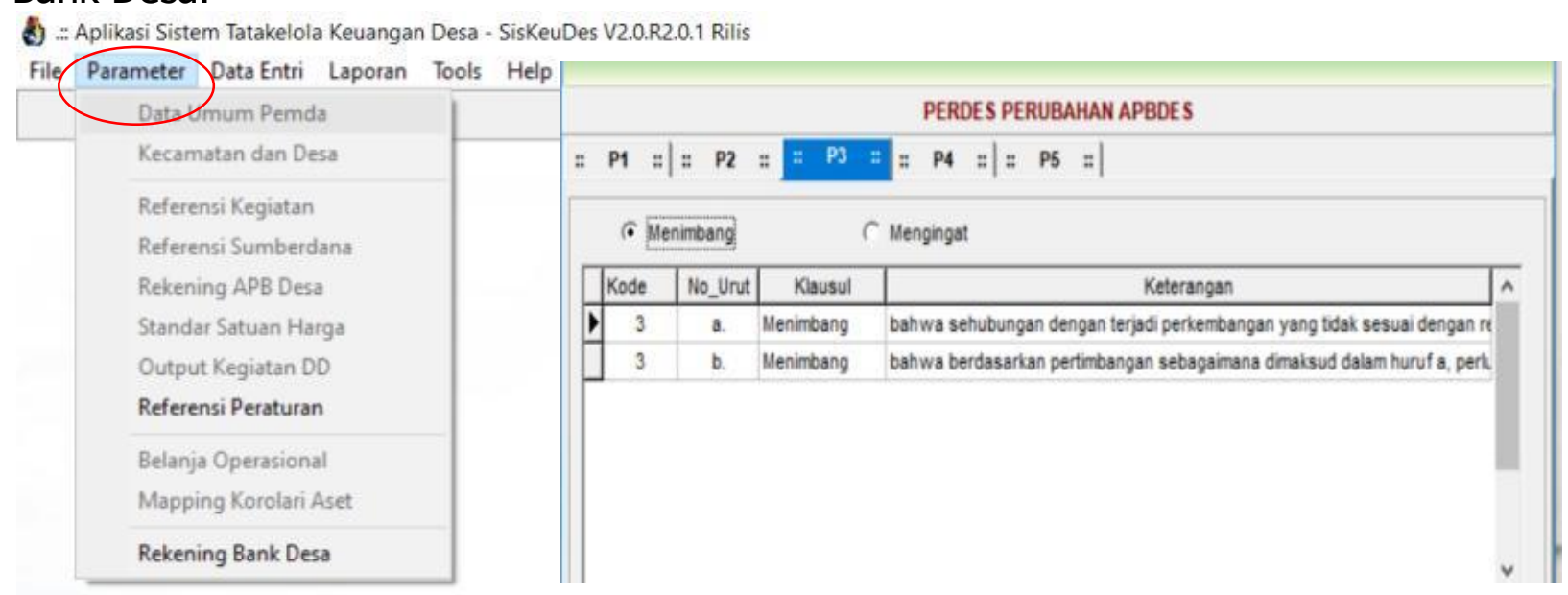

Gambar 1

Tampilan Menu Parameter dan Referensi Peraturan

Dalam Siskeudes V2.0 R.2.0.2, Perdes APBDes dan perubahannya juga harus dirincikan sesuai tahapannya, yaitu:

a. Perdes APBDes (P1)

b. Penjabaran APBDes (P2)

c. Perdes Perubahan APBDes (P3) 
d. Penjabaran Perubahan APBDes (P4)

Secara lebih rinci, berikut tampilan rinci setiap tahap pada setiap versi Siskuedes:

\section{Perencanaan dan Penganggaran}

Tampilan menu Entri Perencanaan dan Penganggaran pada Siskeudes V1.0.R1.06, V2.0 R.0.1, dan V2.0 R.2.0.2 masih sama. Siskeudes V2.0 R.2.0.2 tetap mengintegrasikan dokumen Perencanaan dan Penganggaran. Pada tahap Perencanaan dan Penganggaran, pengisian aplikasi terpecah menjadi "BidangSub Bidang-Kegiatan-Paket Kegiatan". Dengan demikian, untuk jenis belanja yang sama, misalnya belanja barang dan jasa, karena terpisah untuk per kegiatan dan per paket kegiatan, bisa jadi hingga akhir tahun, realisasinya masih sedikit.

Penggunaan sistem paket kegiatan hanya dilakukan untuk Dana Desa (DD), tidak untuk Alokasi Dana Desa (ADD). Oleh karena itu, untuk laporan Dana Desa, kini harus membuat Laporan Capaian Output Dana Desa, untuk mengetahui sudah seberapa jauh pencapaian untuk kegiatan yang akan dilakukan. Selain itu, hal ini juga mempengaruhi Standar Satuan Harga yang digunakan, karena sudah menggunakan paket.

Adanya Paket Kegiatan juga berpengaruh pada penyaluran Dana Desa yang juga terbagi sesuai Paket Kegiatan. Tahapan penyaluran Dana Desa terbagi dalam 3 tahap sesuai PMK 193/PMK.07/2018. Berikut tahapannya:

$\checkmark$ Tahap 1 berupa surat pemberitahuan bahwa Pemerintah Daerah yang bersangkutan telah menyampaikan Peraturan Daerah mengenai APBD tahun anggaran berjalan dan peraturan bupati/walikota mengenai tata cara pembagian (alokasi) dan penetapan rincian Dana Desa setiap Desa.

$\checkmark$ Tahap 2 berupa Laporan Realisasi Penyaluran Dana Desa tahun anggaran sebelumnya; dan Laporan Konsolidasi Realisasi Penyerapan dan Capaian Output Dana Desa tahun anggaran sebelumnya.

$\checkmark$ Tahap 3 berupa Laporan Realisasi Penyaluran Dana Desa sampai dengan tahap 2, Laporan Konsolidasi Realisasi Penyerapan dan Capaian Output Dana Desa sampai dengan tahap 2, dan Laporan Tingkat Konvergensi Pencegahan Stunting Kabupaten/Kota tahun anggaran sebelumnya.

Hal ini diperbarui dengan adanya PMK Nomor 205/PMK.07/2019 tentang Pengelolaan Dana Desa. Jika pada setiap tahapan yang telah dijelaskan di atas tingkat penyaluran Dana Desa yaitu 20\%, 40\%, dan 40\%, perubahan PMK, besar persentase menjadi 40\% (paling lambat dicairkan Juni 2020), 40\% (paling cepat dapat dicairkan Mei dan paling lambat Agustus 2020), dan 20\% (paling cepat dapat dicairkan Juli 2020). Pada 2020, pemerintah pusat juga 
menambah 1 alokasi lagi untuk Alokasi Dana Desa, yang tadinya hanya Alokasi Dasar, Alokasi Afirmasi, dan Alokasi Formula, ditambah dengan Alokasi Kinerja.

\section{Penatausahaan}

Dari segi input data, tidak ada perubahan antara Siskeudes versi sebelumnya. Walaupun sudah menggunakan paket kegiatan, namun jika realisasi diinput melebihi anggaran, hal ini tetap dapat dilakukan. Namun terkait dengan laporan pada tahapan penatausahaan keuangan desa, pada Siskeudes versi 2 dan Siskeudes versi 1 , berikut perbandingan laporan penatausahaan yang harus dibuat oleh desa:
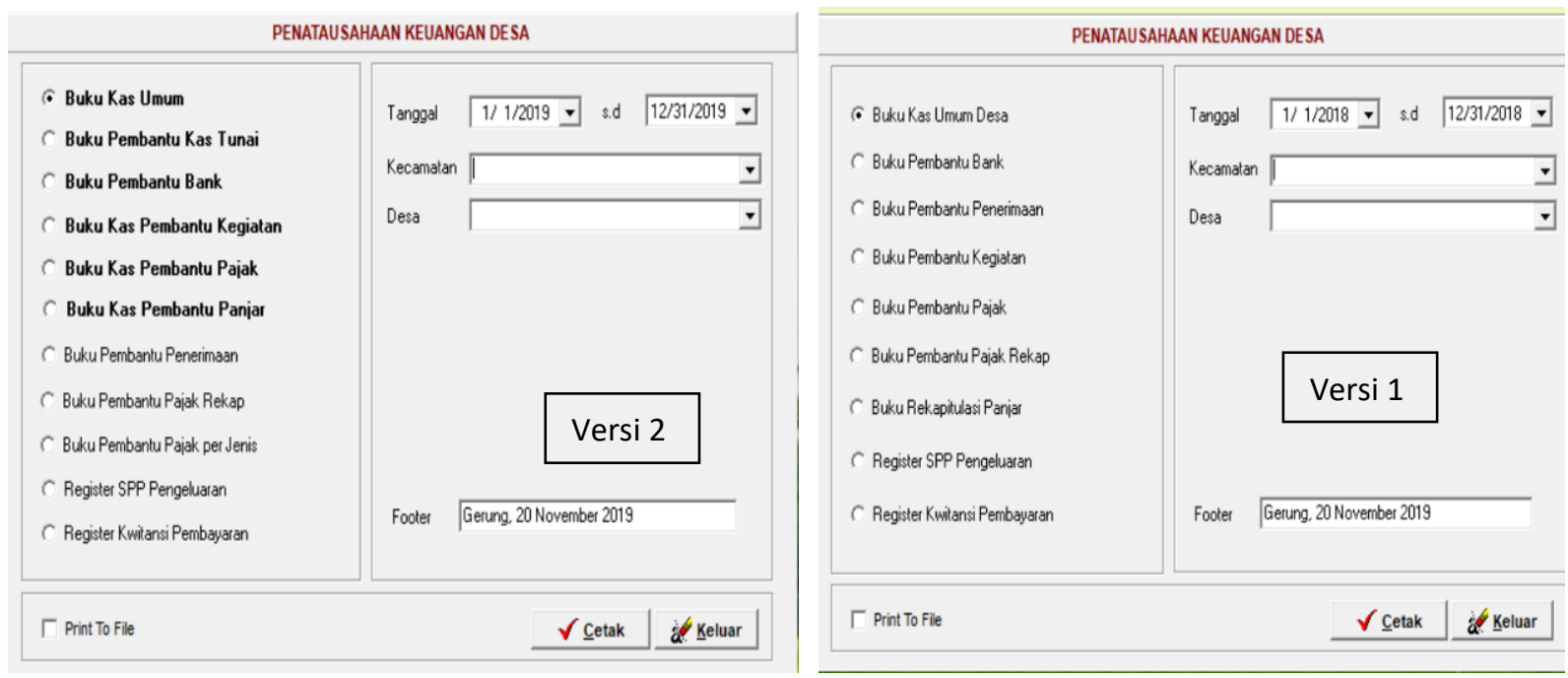

Gambar 2

Perbandingan Menu Laporan pada Penatausahaan Siskeudes Versi 2 dan Versi 1

Sebagaimana dapat dilihat pada gambar 2, pada Siskeudes versi 2, terdapat laporan tambahan yaitu:

$\checkmark$ Buku Pembantu Kas Tunai.

$\checkmark$ Buku Pembantu Pajak dirinci menjadi Buku Kas Pembantu Pajak, Buku Pembantu Pajak Rekap, dan Buku Pembantu Pajak Per Jenis.

Dalam menu dokumen dan laporan pajak, terdapat pula penambahan fitur pajak dengan kode 7.1.1.xx untuk pajak pusat, dan 7.1.2.xx untuk pajak daerah, penambahan informasi Nomor Transaksi Penerimaan Negara (NTPN) pada saat penyetoran pajak, dan penambahan informasi nomor SPP pada formulir Surat Pernyataan Tanggung Jawab Belanja (SPTB). Hanya sayangnya, 
sama seperti Siskeudes versi 1, untuk pajak, karena peraturan kabupaten dan kota dengan objek pajak yang beragam, ditambah peraturan pajak pusat, belum ada deteksi otomatis untuk objek pajak yang berbeda dikenakan pajak pusat atau pajak daerah, dan berdasarkan peraturan bupati atau gubernur, masih belum ada perancangan deteksi peraturan otomatis pada Siskeudes V2.0 R.2.0.2.

Tahap Penatausahaan juga tergantung pada tahap Pelaksanaan. Sejak Siskeudes V2.0 R.0.1, pada tahap Pelaksanaan, operator desa belum bisa mengisi belanja jika belum terinput kegiatannya di Perencanaan dan Penganggaran, karena pada menu Belanja Desa, menunya tersambung, yaitu pada menu "Bidang-Kegiatan-RAB-RAB Rinci". Hal ini tidak hanya berlaku pada pos belanja, namun juga pada pos Pembiayaan juga demikian, dengan adanya menu "Bidang-Kegiatan-RAP-RAP Rinci".

Akan tetapi, walaupun datanya terkoneksi, namun datanya belum terkunci. Dengan demikian, jika Kaur Keuangan telah mengentri data pada penatausahaan, data yang dimasukan oleh Kaur Keuangan tersebut masih dapat dihapus, walaupun menunya sudah tersambung. Hal yang sama juga terjadi pada SPP Definitif, yang hanya terhubung dengan Kegiatan di Penganggaran, tapi tidak terkunci.

\section{Pembukuan}

Dalam tahap Laporan untuk Pembukuan, terdapat perbedaan, yaitu adanya Laporan Realisasi APBDesa pada versi Siskeudes yang baru, karena mengikuti Permendagri No.20 Tahun 2018. Laporan juga harus diinformasikan kepada masyarakat melalui media informasi, dan tidak hanya memuat Laporan Realisasi APBDesa, namun juga Laporan Realisasi Kegiatan, Laporan Kegiatan yang Belum Selesai dan/atau Tidak Terlaksana, serta sisa anggaran. Gambar 3 menunjukkan perbedaan pembukuan Siskeudes Versi 2 dan Siskeudes Versi 1. 

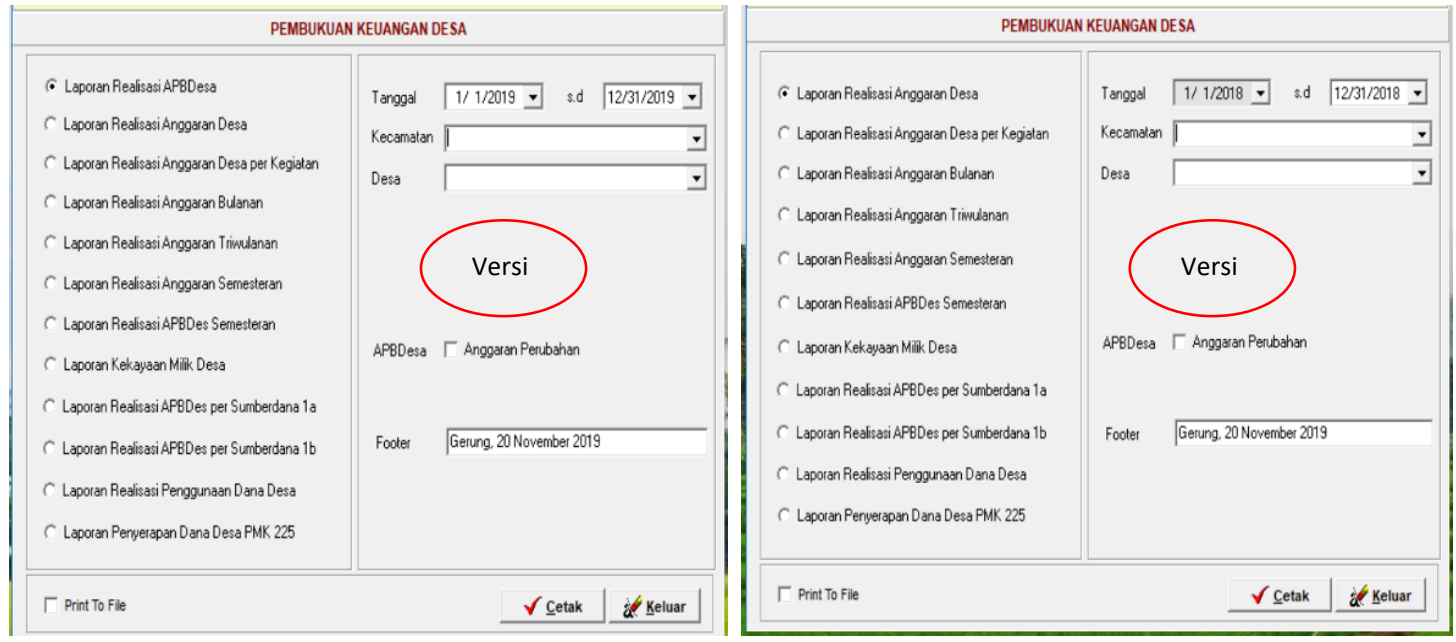

Gambar 3

Menu Pembukuan Keuangan Desa

Laporan lainnya adalah Laporan Realisasi Kegiatan. Menurut Permendagri Nomor 20 Tahun 2018, laporan ini disusun dengan menggabungkan laporan akhir realisasi pelaksanaan kegiatan dan anggaran. Laporan gabungan ini disetorkan oleh Kepala Desa paling lambat minggu kedua bulan Juli tahun berjalan.

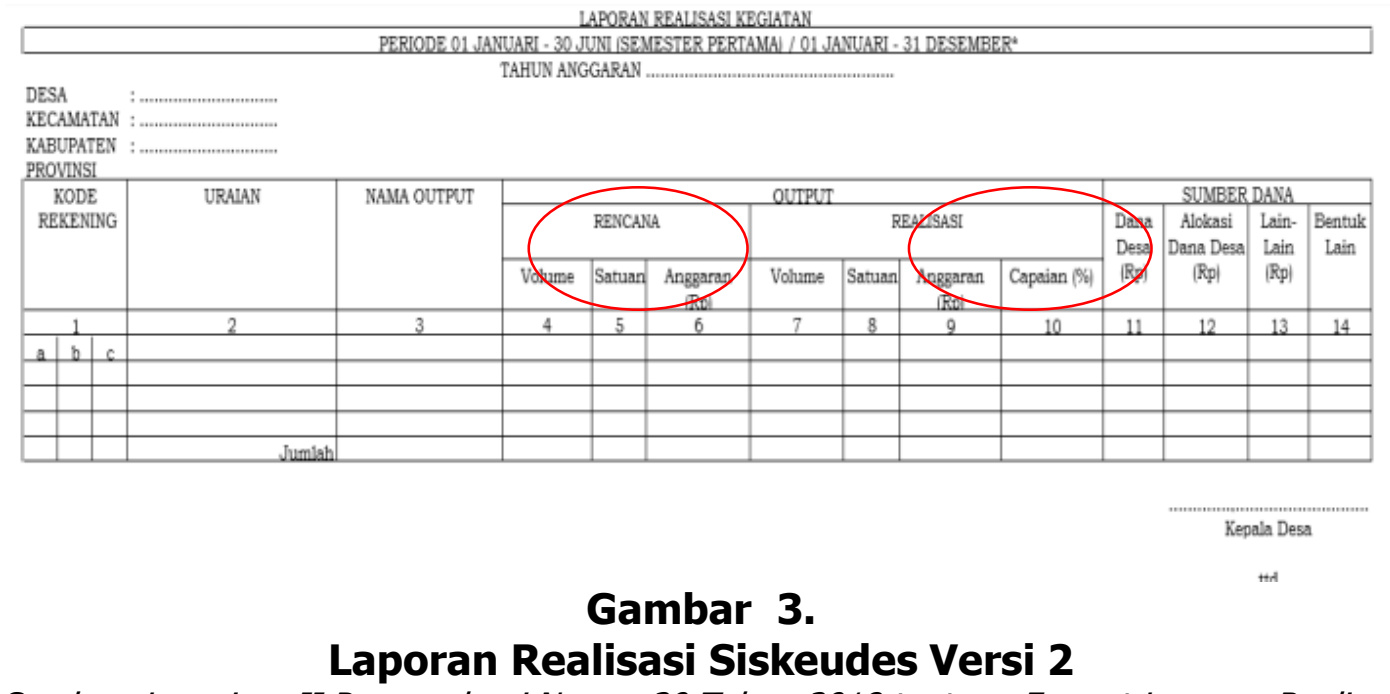

Sumber: Lampiran II Permendagri Nomor 20 Tahun 2018 tentang Format Laporan Realisasi Kegiatan 


\section{Pelaporan}

Pada Siskeudes V2.0 R.2.0.2, terdapat penambahan laporan akhir, yaitu Laporan RAK (Rencana Anggaran Kas) Bulanan, Laporan Penjabaran APBDesa, Laporan DPAL (Daftar Pelaksanaan Anggaran Lanjutan) dan laporan Realisasi Dana Desa. Sebagaimana dapat dilihat pada tampilan gambar 6, RAK desa menggunakan termin (yang terhubung dengan Paket Kegiatan Belanja). Desa harus dapat memperkirakan kapan dan bulan apa Dana Desa masuk dalam Rekening Desa untuk dicairkan. Dengan demikian, jika perkiraaan desa keliru, RAK bisa keliru, dan Siskeudes tidak akan bisa dioperasikan, karena terkunci otomatis. Penguncian aplikasi hanya dapat dibuka oleh verifikator DPMD.

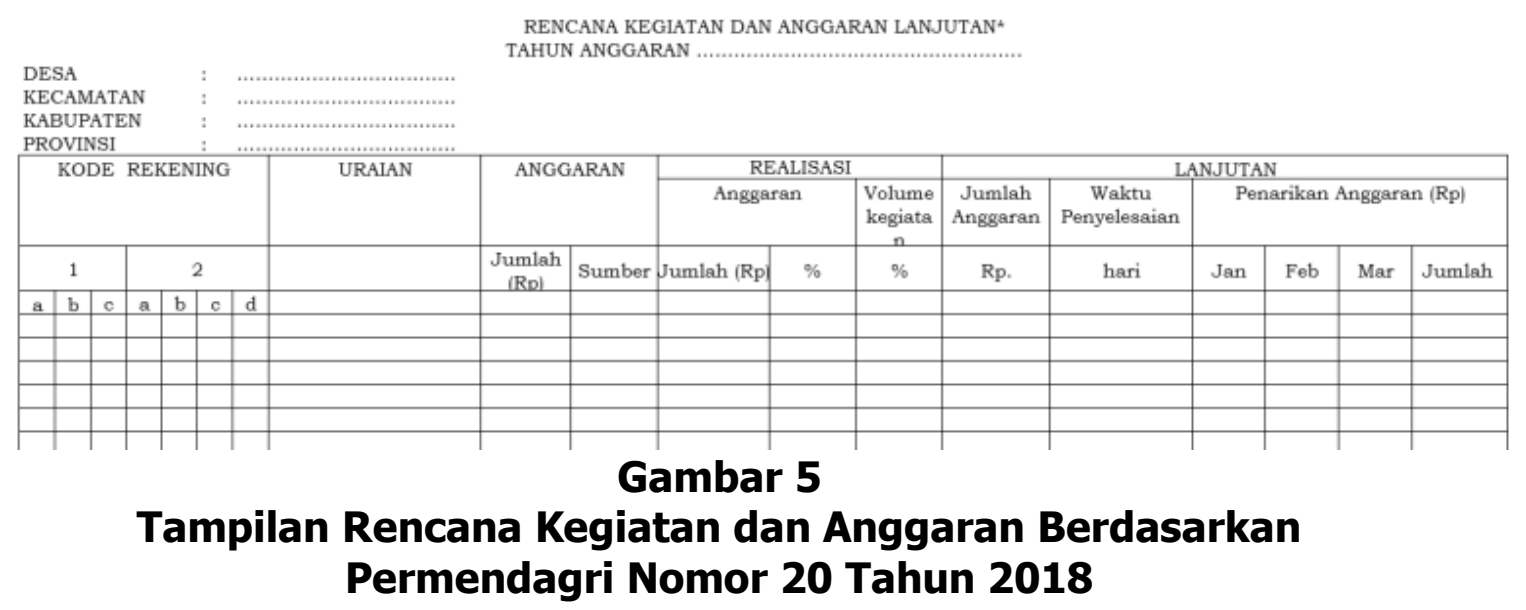

Transfer Laporan ke Kementerian Melalui OM-SPAN

Melalui pemanfaatan teknologi dalam Siskeudes, mekanisme pelaporan dalam rangka pelaksanaan Dana Desa (DD) oleh para aparat desa ke pusat dapat dilakukan melalui Siskeudes. Untuk mengintegrasikan pengelolaan dan pelaporan Dana Desa (DD) dengan pusat (kementerian), Kementerian telah melakukan koordinasi dan sinkronisasi melalui Online Monitoring Sistem Perbendaharaan dan Anggaran Negara (OM-SPAN). Dengan demikian, OMSPAN menjadi media ekspor impor data realisasi output Dana Desa. Selain itu, OM-SPAN juga menjadi persyaratan pula untuk penyaluran DD dari Rekening Kas Umum Negara (RKUN) ke Rekening Kas Umum Daerah (RKUD). Hal ini juga terkait dengan kualitas sistem. Pelaporan masih dilakukan oleh verifikator kabupaten, namun desa sendiri masih offline, terutama karena masalah lokasi desa.

Namun jika dilihat dari tampilan aplikasinya, Siskeudes V2.0 R.2.0.2 seharusnya lebih memudahkan para aparat pengelola keuangan desa, karena walaupun pada interface dan formulir maupun dokumen terdapat banyak 
perubahan bahkan penambahan, namun basis yang digunakan sudah diturunkan menjadi basis kas.

\section{SIMPULAN}

Dari kualitas proses dan kualitas informasi, penggunaan Siskeudes Versi 2.0 R.0.1. lebih baik dari segi proses input hingga penatausahaan dan pembukuannya, dan sudah terintegrasi dengan dokumen pada tahap perencanaan dan penganggaran, dibandingkan dengan Siskeudes Versi 1.0.R1.06. Mulai dari tahap Perencanaan, Siskeudes Versi 2 sudah menggunakan Paket Kegiatan dalam pos Belanja, sehingga desa harus mampu memperkirakan belanja yang akan dihabiskan dalam realisasi kegiatan.

Dalam Siskeudes Versi 2, dalam tahap berkas laporan (output), sudah terdapat pula penambahan laporan, mulai laporan pada tahap perencanaan, penganggaran, penatausahaan, pembukuan, hingga karena menyesuaikan dengan Permendagri Nomor 20 Tahun 2018 dan PMK 193/PMK.07/2018, sehingga laporan yang dihasilkan beserta informasinya lebih rinci, bahkan hingga detailnya untuk laporan terkait pajak dan realisasi kegiatan.

Terkait kualitas sistem, banyak desa yang bisa jadi masih menggunakan sistem offline untuk melaporkan data ke DPMD, karena banyak lokasi desa yang masih sulit dijangkau. Akan tetapi, verifikator kabupaten sudah menggunakan OM-SPAN untuk pelaporan ke kementerian sejak Siskeudes Versi 2.0 R.0.1.

Namun sebagai saran, karena memandang terbatasnya pemahaman aparat pengelola keuangan desa terkait tahap pengelolaan keuangan desa dengan basis kas, ditambah dengan tenaga verifikator yang terbatas pada kebanyakan kabupaten di Indonesia, maka perlu pula ada pelatihan lanjutan bagi para pendamping desa, bahkan kecamatan, agar dapat menyelenggarakan pendampingan dan pelatihan atas sistem informasi yang digunakan secara berkesinambungan atau pelatihan yang teratur dan sistematis. Terlebih karena aplikasi ini masih terus dikembangkan oleh BPKP dan Kementerian Desa dan Pembangunan Daerah Tertinggal, serta Kementerian Dalam Negeri, maka penelitian lanjutan juga masih perlu dilakukan. 
Intan Rakhmawati \& Siti Atikah: Kualitas Informasi Sistem Keuangan Des.....

\section{DAFTAR PUSTAKA}

Badan Pengawasan Keuangan dan Pembangunan. 2018. Badan Pengawasan Keuangan dan Pembangunan. Sistem Keuangan Desa (SISKEUDES) Manual Operasi Aplikasi SISKEUDES 2.0. Jakarta: Deputi Bidang Pengawasan Penyelenggaraan Keuangan Daerah.

- 2017. Pengawalan Akuntabilitas Keuangan Desa, Sosialisasi Pengelolaan Dana Desa Bagi Pembina dan Pengawas Desa Tahun Anggaran 2017. Jakarta: Deputi Bidang Pengawasan Penyelenggaraan Keuangan Daerah.

- 2017. Pengawalan Akuntabilitas Keuangan Desa-Sosialisasi Pengelolaan Keuangan Desa. Singaraja: 20 November 2017.

—. 2016. Badan Pengawasan Keuangan dan Pembangunan. Modul Pengelolaan Keuangan Desa \# 4 Modul Aplikasi Sistem Keuangan Desa (SISKEUDES). Jakarta: Deputi Bidang Pengawasan Penyelenggaraan Keuangan Daerah.

- 2015. Petunjuk Pelaksanaan Bimbingan dan Konsultasi Pengelolaan Keuangan Desa. Jakarta: Deputi Bidang Pengawasan Penyelenggaraan Keuangan Daerah.

Hendri, Sapto, Ni Putu Ayu Candra, Intan Rakhmawati, and Siti Atikah. 2016. Pengaruh Sumber Daya Manusia, Sarana dan Prasarana Terhadap Kinerja Pengelolaan Keuangan Desa di Kabupaten Lombok Tengah. Conference Management and Behavioral Studies, ISSN:2541-3400. Jakarta: Universitas Tarumanegara.

Husna, Saifatul, and Syukriy Abdullah. 2016. Kesiapan Aparatur Desa Dalam Pelaksanaan Pengelolaan Keuangan Desa Secara Akuntabilitas Sesuai Undang-Undang Nomor 6 Tahun 2014 Tentang Desa (Studi Pada Beberapa Desa di Kabupaten Pidie). Jurnal Ilmiah Mahasiswa Ekonomi Akuntansi (JIMEKA) Volume 1 Nomor 1, 282-293.

Juardi, Muhammad Sapril Sardi, Mustakim Muchlis, dan Reski Amalia Putri. Evaluasi Penggunaan Aplikasi Siskeudes dalam Upaya Peningkatan Kualitas Akuntabilitas Keuangan Desa (Studi Pada Desa Jenetallasa Kec. Pallangga Kab. Gowa). Jurnal IImiah Akuntansi Peradaban Vol. IV No. 1, Juni 2018: 84-107, ISSN: 2442-3017 (PRINT), ISSN: 2597-9116 (ONLINE).

alauddin.ac.id/index.php/jiap/article/view/5159/4627

Kementerian Dalam Negeri Republik Indonesia. 2018. Peraturan Menteri Dalam Negeri Nomor 20 Tahun 2018 tentang Pengelolaan Keuangan Desa. Jakarta: Kementerian Dalam Negeri Republik Indonesia. 
2014. Peraturan Menteri Dalam Negeri Nomor 113 Tahun 2014 tentang Pengelolaan Keuangan Desa. Jakarta: Kementerian Dalam Negeri Republik Indonesia.

- 2014. Peraturan Menteri Dalam Negeri Nomor 114 Tahun 2014 tentang Pedoman Pembangunan Desa. Jakarta: Kementerian Dalam Negeri Republik Indonesia.

Kementerian Desa, Pembangunan Daerah Tertinggal, dan Transmigrasi Republik Indonesia. 2018. Peraturan Menteri Desa, Pembangunan Daerah Tertinggal, dan Transmigrasi Nomor 16 Tahun 2018 tentang Prioritas Penggunaan Dana Desa Tahun 2019. Jakarta: Kementerian Desa, Pembangunan Daerah Tertinggal, dan Transmigrasi Republik Indonesia.

Kementerian Keuangan Republik Indonesia. 2019. Peraturan Menteri Keuangan Nomor 205/PMK.07/2019 tentang Pengelolaan Dana Desa. Jakarta: Kementerian Keuangan Republik Indonesia.

__ 2017. Peraturan Menteri Keuangan Nomor 225 Tahun 2017 tentang Perubahan Kedua atas Peraturan Menteri Keuangan Nomor 50/PMK.07/2017 tentang Pengelolaan Transfer ke Daerah dan Dana Desa. Jakarta: Kementerian Keuangan Republik Indonesia.

- 2016. Peraturan Menteri Keuangan Nomor 49 Tahun 2016 tentang Tata Cara Pengalokasian, Penyaluran, Penggunaan, Pemantauan, dan Evaluasi Dana Desa. Jakarta: Kementerian Keuangan Republik Indonesia.

—_. Peraturan Menteri Keuangan Nomor 93 Tahun 2015 tentang Tata Cara Pengalokasian, Penyaluran, Penggunaan, Pemantauan, dan Evaluasi Dana Desa. Jakarta: Kementerian Keuangan Republik Indonesia.

- 2015. Peraturan Menteri Keuangan Nomor 247 Tahun 2015 tentang Tata Cara Pengalokasian, Penyaluran, Penggunaan, Pemantauan, dan Evaluasi Dana Desa. Jakarta: Kementerian Keuangan Republik Indonesia.

_. 2013. Peraturan Menteri Keuangan Nomor 146 Tahun 2013 tentang Perubahan Kedua atas Peraturan Menteri Keuangan Nomor 154/PMK.03/2010 tentang Pemungutan Pajak Penghasilan Pasal 22 Sehubungan dengan Pembayaran atas Penyerahan Barang dan Kegiatan di Bidang Impor atau Kegiatan Usaha di Bidang Lain. Jakarta: Kementerian Keuangan Republik Indonesia.

- 2003. Keputusan Menteri Keuangan Nomor 563 Tahun 2003 tentang Penunjukan Bendaharawan Pemerintah dan Kantor Perbendaharaan dan Kas Negara Untuk Memungut, Menyetor, dan Melaporkan Pajak 
Intan Rakhmawati \& Siti Atikah: Kualitas Informasi Sistem Keuangan Des.....

Pertambahan Nilai dan Pajak Penjualan atas Barang Mewah beserta Tata Cara Pemungutan, Penyetoran, dan Pelaporannya. Jakarta: Kementerian Keuangan Republik Indonesia.

Peraturan Pemerintah Nomor 8 Tahun 2016 tentang Perubahan Kedua atas Peraturan Pemerintah Nomor 60 Tahun 2014 tentang Dana Desa yang Bersumber dari Anggaran Pendapatan dan Belanja Negara.

Peraturan Pemerintah Nomor 47 Tahun 2015 tentang Perubahan atas Peraturan Pemerintah Nomor 43 Tahun 2014 tentang Peraturan Pelaksanaan Undang-Undang Nomor 6 tahun 2014 tentang Desa.

Peraturan Pemerintah Nomor 22 Tahun 2015 tentang Perubahan atas Peraturan Pemerintah Nomor 60 Tahun 2014 tentang Dana Desa yang Bersumber dari Anggaran Pendapatan dan Belanja Negara.

Peraturan Pemerintah Nomor 43 Tahun 2014 tentang Peraturan Pelaksanaan UndangUndang Nomor 6 tahun 2014 tentang Desa.

Peraturan Pemerintah Nomor 60 Tahun 2014 tentang Dana Desa yang Bersumber dari Anggaran Pendapatan dan Belanja Negara.

Muhsyaf, Saipul Arni, Siti Atikah, dan Widia Astuti. 2016. Analisis Pengelolaan Keuangan Desa Sebagai Bentuk Implementasi Undang-Undang Nomor 6 tahun 2014 Tentang Desa. Jurnal Riset Akuntansi Aksioma, Volume 15, No.1, ISSN 1858-0785, 60-69.

Munti, Finta, and Heru Fahlevi. 2017. Determinan Kinerja Pengelolaan Keuangan Desa: Studi Pada Kecamatan Gandapura Kabupaten Bireuen Aceh. Jurnal Akuntansi dan Investasi, Volume 8 No.12, doi 10.18196/jai.180281, 172-182.

Subchan, Nur, Endang Siti Astuti, Kertahadi. 2012. Mengukur Efektivitas Sistem Informasi dan Mengetahui Kesuksesan Portal Akademik (SIAM) On-line (Studi Kasus Terhadap Pengguna di Program Pendidikan Vokasi Universitas Brawijaya). Jurnal Profit, Volume 6 No. 2, doi 10.9876, 117-134.

Subiakto, Henry. 2001. Analisis Isi Media, Metode dan Pemanfaatannya. Metodologi Penelitian Kualitatif by Burhan Bungin, 185 - 198. Jakarta: PT. Raja Grafindo Persada, 2001.

Sugiyono. 2017. Metode Penelitian dan Pengembangan (Research and Development) untuk Bidang Pendidikan, Manajemen, Sosial, Teknik. Bandung: Penerbit Alfabeta.

Suhaedi, Wirawan, Baiq Rosyida Dwi Astuti, dan Alamsyah. 2016. Evaluasi Pengelolaan Keuangan Desa. Jurnal Riset Akuntansi Aksioma, 34-45.

Sulina, I Gusti Ayu Trisha, Made Arie Wahyuni, dan Putu Sukma Kurniawan. 2017. Peranan Sistem Keuangan Desa (Siskuedes) Terhadap Kinerja Pemerintah Desa (Studi Kasus di Desa Kaba-Kaba, Kecamatan Kediri, Kabupaten Tabanan. e-Journal S1 Ak Universitas Pendidikan Ganesha Jurusan Akuntansi Program S1 Volume 8 Nomor 2. 